\title{
DEMONSTRATION OF AN ACTIVE C17-C20 LYASE IN THE SHEEP PLACENTA
}

\author{
BARBARA M. JOHN AND G. G. PIERREPOINT \\ Tenovus Institute for Cancer Research, \\ Welsh National School of Medicine, \\ The Heath, Cardiff CF4 $4 X X$
}

(Received 27th November 1974)

Studies on the sheep have provided more information concerning the hormonal changes that precede parturition than those on any other mammal. The implications of some of the findings are uncertain but a composite picture is gradually emerging.

The ability of sheep placenta to convert $\mathrm{C}_{19}$-steroids to oestrogens (Ainsworth \& Ryan, 1966; Pierrepoint, Anderson, Griffiths \& Turnbull, 1970a) and their sulphates (Pierrepoint, Anderson, Harvey, Turnbull \& Griffiths, 1971) has been well demonstrated although neither a source nor the species of such potential precursors has been found.

Two of the most active $\mathrm{C}_{21}$-steroid-metabolizing enzymes in the sheep placenta are the $20 \alpha$-hydroxysteroid dehydrogenase and the $3 \beta$-hydroxysteroid dehydrogenase $-\Delta^{4}-\Delta^{5}$-isomerase with the consequent formation of large amounts of progesterone and 20 $\alpha$-dihydroprogesterone (Ainsworth \& Ryan, 1967; Pierrepoint et al., 1970b; Pierrepoint, Anderson, Turnbull \& Griffiths, 1973). Steroid $17 \alpha$-hydroxylase and $\mathrm{C}_{21}$-steroid $\mathrm{C} 17-\mathrm{C} 20$ lyase activity have been shown, although the products of their combined actions amounted to less than $1 \%$ of the precursors (Pierrepoint et al., 1970b, 1973).

Because of these findings and the current acceptance that the 'desmolase' enzyme cannot act without the prior $17 \alpha$-hydroxylation of the $\mathrm{C}_{21}$-steroid (Slaunwhite \& Samuels, 1956; Lynn \& Brown, 1958; Ellis \& Berliner, 1965), the ability of the sheep placenta to metabolize $17 \alpha$-hydroxylated $\mathrm{C}_{21}$-steroid substrates was investigated, with particular regard to the formation of $\mathrm{C}_{19^{-}}$and $\mathrm{C}_{18}$-products.

Placental tissue was removed at hysterotomy from a ewe at 119 days of gestation and transported to the laboratory on ice. A minced preparation (4 g) was added to $24 \mathrm{ml}$ Krebs-Ringer bicarbonate glucose solution containing $10 \mu \mathrm{Ci}\left[7 \alpha-{ }^{3} \mathrm{H}\right] 17 \alpha$-hydroxypregnenolone $(179.5 \mathrm{Ci} / \mathrm{mol})$ and $2 \mu \mathrm{Ci}\left[4-{ }^{14} \mathrm{C}\right] 17 \alpha-$ hydroxyprogesterone $(35.9 \mathrm{Ci} / \mathrm{mol})$, both supplied by Amersham Radiochemical Centre, Bucks. The mixture was shaken in an atmosphere of $95 \%$ $\mathrm{O}_{2}: 5 \% \mathrm{CO}_{2}$ for $2 \mathrm{hr}$ in a water bath at $39.5^{\circ} \mathrm{C}$. After the incubation period, the reaction was stopped by the addition of $30 \mathrm{ml}$ acetone and refrigeration.

Metabolism was assessed by the reverse-isotope dilution method. Steroids to be investigated (17 $\alpha$-hydroxypregnenolone 17 $\alpha$-hydroxyprogesterone, dehydroepiandrosterone (DHA), androstenedione, testosterone, epitestosterone, oestradiol-17 $\beta$, oestradiol-17 $\alpha$, oestrone, DHA sulphate, oestrone sulphate and 
oestradiol-17 $\beta$-3-sulphate) were added in 300- $\mu$ g amounts in ethanol. The method of extraction, purification and identification of the metabolites has previously been described (Pierrepoint et al., 1970a, 1971). The solvent systems employed ( $\mathrm{v} / \mathrm{v}$ or by vol.) in the thin-layer chromatographic procedures were: (I) chloroform:acetone, $37: 3$; (II) cyclohexane: ethyl acetate, 1:1; (III) cyclohexane: ethyl acetate, $9: 11$; (IV) tertiary butanol:ethyl acetate:5 Nammonium hydroxide, 41:50:20; (V) hexane:ethyl acetate, 1:1; (VI) cyclohexane: ethyl acetate, 3:1; (VII) benzene:ethyl acetate, 9:1; (VIII) hexane: ethyl acetate, $3: 2$.

Table 1. Evidence for the identification of the steroids isolated following incubation of sheep placenta with labelled $17 \alpha$-hydroxylated $\mathrm{C}_{21}$-steroids

\begin{tabular}{|c|c|c|c|c|c|}
\hline \multirow[t]{2}{*}{ Steroid investigated and derivative formed } & \multirow[t]{2}{*}{$\begin{array}{l}\text { Solvent } \\
\text { system }\end{array}$} & \multicolumn{2}{|c|}{$\begin{array}{l}\text { Specific activities } \\
(d / \mathrm{min} / \mathrm{nmol})\end{array}$} & \multicolumn{2}{|c|}{$\begin{array}{l}\% \text { of initial radioactivity } \\
\text { associated with the } \\
\text { investigated steroids }\end{array}$} \\
\hline & & ${ }^{3} \mathrm{H}$ & ${ }^{14} \mathrm{C}$ & ${ }^{3} \mathrm{H}$ & ${ }^{14} \mathrm{C}$ \\
\hline $\begin{array}{l}\text { 17 } \alpha \text {-Hydroxypregnenolone } \\
17 \alpha \text {-Hydroxypregnenolone acetate }\end{array}$ & $\begin{array}{l}\text { I, III } \\
\text { VI }\end{array}$ & $\begin{array}{l}998 \cdot 8 \\
917 \cdot 5\end{array}$ & 0 & $2 \cdot 00$ & 0 \\
\hline $\begin{array}{l}\text { 17 } \alpha \text {-Hydroxyprogesterone } \\
17 \alpha, 20 \beta \text {-Dihydroxypregn-4-en-3-one } \\
17 \alpha \text {-Hydroxypregn-4-en-3-one-20 } \beta \text {-acetate }\end{array}$ & $\begin{array}{l}\text { I, III, VIII } \\
\text { I }\end{array}$ & I $\begin{array}{l}10.06 \\
12.08 \\
15.07\end{array}$ & $\begin{array}{l}78 \cdot 94 \\
70 \cdot 11 \\
76 \cdot 42\end{array}$ & 0.03 & $1 \cdot 90$ \\
\hline $\begin{array}{l}\text { Androstenedione } \\
\text { Testosterone } \\
\text { Testosterone acetate }\end{array}$ & $\begin{array}{l}\text { I,II } \\
\text { I, III } \\
\text { VI }\end{array}$ & $\begin{array}{l}26 \cdot 33 \\
27 \cdot 01 \\
25 \cdot 91\end{array}$ & $\begin{array}{l}1 \cdot 60 \\
1.58 \\
1 \cdot 84\end{array}$ & $0 \cdot 06$ & $0 \cdot 05$ \\
\hline $\begin{array}{l}\text { Testosterone } \\
\text { Androstenedione } \\
\text { Testosterone }\end{array}$ & $\begin{array}{l}\text { I, III, II } \dagger \\
\text { I, II } \\
\text { VI }\end{array}$ & $\begin{array}{l}5 \cdot 54 \\
5 \cdot 58 \\
5 \cdot 91\end{array}$ & 0 & $0 \cdot 01$ & 0 \\
\hline $\begin{array}{l}\text { Epitestosterone } \\
\text { Androstenedione } \\
\text { Epitestosterone acetate }\end{array}$ & $\begin{array}{l}\text { I, II } \dagger \\
\text { I, II } \\
\text { VI }\end{array}$ & $\begin{array}{l}69 \cdot 91 \\
65 \cdot 45 \\
67 \cdot 81\end{array}$ & $\begin{array}{l}0 \cdot 86 \\
0 \cdot 81 \\
0 \cdot 83\end{array}$ & $0 \cdot 16$ & $0 \cdot 02$ \\
\hline $\begin{array}{l}\text { DHA } \\
\text { Androst-5-ene-3 } \beta, 17 \beta \text {-diol } \\
\text { DHA acetate }\end{array}$ & $\begin{array}{l}\text { I, III, VIII } \\
\text { II } \\
\text { VI }\end{array}$ & I $\begin{array}{r}44 \cdot 57 \\
46 \cdot 94 \\
43 \cdot 68\end{array}$ & 0 & $0 \cdot 01$ & 0 \\
\hline $\begin{array}{l}\text { Oestrone } \\
\text { Oestrone acetate } \\
\text { Oestradiol-17 } \beta \text {-3-methyl ether }\end{array}$ & $\begin{array}{l}\text { I, II } \\
\text { VI } \\
\text { VII }\end{array}$ & $\begin{array}{l}140 \cdot 8 \\
147 \cdot 0 \\
153 \cdot 1\end{array}$ & $\begin{array}{l}4 \cdot 19 \\
5 \cdot 08 \\
3 \cdot 62\end{array}$ & $0 \cdot 34$ & $0 \cdot 14$ \\
\hline $\begin{array}{l}\text { Oestradiol-17 } \beta \\
\text { Oestradiol-17 } \beta \text {-diacetate } \\
\text { Oestradiol-17 } \beta \text {-3-methyl ether }\end{array}$ & $\begin{array}{l}\text { I, III, VI } \\
\text { VI } \\
\text { VII }\end{array}$ & $\begin{array}{l}13 \cdot 35 \\
12 \cdot 87 \\
12 \cdot 23\end{array}$ & $\begin{array}{l}0.29 \\
0.35 \\
0.37\end{array}$ & 0.03 & $0 \cdot 01$ \\
\hline $\begin{array}{l}\text { Oestradiol-17 } \\
\text { Oestradiol-17 } 1 \text {-diacetate } \\
\text { Oestradiol-17 } \alpha \text {-3-methyl ether }\end{array}$ & $\begin{array}{l}\text { I, III, VI } \\
\text { VI } \\
\text { VII }\end{array}$ & $\begin{array}{l}47 \cdot 31 \\
49 \cdot 19 \\
49 \cdot 86\end{array}$ & $\begin{array}{l}1.55 \\
1.43 \\
1.58\end{array}$ & $0 \cdot 12$ & 0.04 \\
\hline $\begin{array}{l}\text { DHA sulphate } \\
\text { DHA } \\
\text { Androst-5-ene-3 } \beta, 17 \beta \text {-diol }\end{array}$ & $\begin{array}{l}\text { IV } \\
\text { I, III, VIII } \\
\text { II }\end{array}$ & $\begin{array}{l}25 \cdot 71 \\
25 \cdot 55\end{array}$ & 0 & $0 \cdot 05$ & 0 \\
\hline $\begin{array}{l}\text { Oestrone sulphate } \\
\text { Oestrone } \\
\text { Oestrone acetate } \\
\text { Oestrone-3-methyl ether }\end{array}$ & $\begin{array}{ll}\text { IV } & \\
\text { II } & 2 \\
\text { VI } & 2 \\
\text { VII } & 2\end{array}$ & $\begin{array}{l}2273 \cdot 3 \\
2483 \cdot 5 \\
2378 \cdot 0\end{array}$ & $\begin{array}{l}77 \cdot 29 \\
79 \cdot 90 \\
73 \cdot 07\end{array}$ & $6 \cdot 07$ & $2 \cdot 43$ \\
\hline 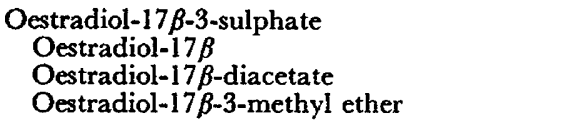 & $\begin{array}{l}\text { IV } \\
\text { I, III, VI } \\
\text { VI } \\
\text { VII }\end{array}$ & $\begin{array}{l}37 \cdot 02 \\
40 \cdot 89 \\
35 \cdot 10\end{array}$ & $\begin{array}{l}1.40 \\
1.67 \\
1.06\end{array}$ & 0.07 & 0.03 \\
\hline
\end{tabular}

* See text for solvents.

† Chromatographed on Merck alumina $\mathbf{P F}_{254 / 366}$ (Type T); Merck Silica gel HF $254 / 366$ (Type 60) was used at all other times. 
The results are shown in Table 1.

Virtually complete metabolism of the two substrates took place with the formation of a range of $\mathrm{C}_{19}$ - and $\mathrm{C}_{18}$-steroids and their conjugates. The major metabolites, estimated by scanning the radioactivity on thin-layer plates, appeared to be the 20-reduced products of both substrates, accounting for approximately $79 \%$ and $93 \%$ respectively of the initial tritium and ${ }^{14} \mathrm{C}$ radioactivity. These steroids were not investigated further and are not included in Table 1 but raise the question of their own participation in the formation of $\mathrm{C}_{19^{-}}$and $\mathrm{C}_{18^{-}}$-steroids.

Of the metabolites characterized, oestrone sulphate was again (Pierrepoint et al., 1973) the principal product, followed by oestrone and epitestosterone. The total 'desmolase' activities for the two substrates, $17 \alpha$-hydroxypregnenolone and $17 \alpha$-hydroxyprogesterone, were very much greater than those achieved using pregnenolone or progesterone and support the findings of a previous report on 11-deoxycortisol (Pierrepoint \& co-authors, 1974) that 17 $\alpha$-hydroxylated $\mathrm{C}_{21}$-steroids can act as substrates for placental $\mathrm{C}_{17}-\mathrm{C}_{20}$ lyase.

Davies, Ryan \& Petro (1970) failed to find oestrone after incubating sheep placenta alone with tritiated pregnenolone but when the tissue was co-incubated with maternal or fetal adrenals, a $0.1 \%$ and $0.17 \%$ conversion was achieved. This low yield may be accounted for by the poor ability of the fetal adrenal to form $\mathrm{C}_{19}$-steroids from 17-deoxy- $\mathrm{C}_{21}$-precursors (Davies et al., 1970; Anderson, Pierrepoint, Jones, Griffiths \& Turnbull, 1970), the order of which is similar to that achieved in the placenta (Pierrepoint et al., 1973).

The implications from these results may be that there is less evidence for the existence of a feto-placental unit in the sheep as defined for women at midpregnancy (Diczfalusy, 1969), unless some of the $17 \alpha$-hydroxylated steroids arise in the fetus. The placenta, on the other hand, may be the site of all the steroid reactions from cholesterol to oestrogen synthesis with controlling factors originating in the fetus.

The authors are grateful to the Tenovus Organization, Cardiff, for generous financial assistance and to $\mathrm{Dr} \mathrm{R}$. I. Cox, conversations with whom lead to the setting up of these experiments.

\section{REFERENGES}

Ainsworth, L. \& RYAN, K. J. (1966) Steroid hormone transformation by endocrine organs from pregnant mammals. I. Estrogen biosynthesis by mammalian placental preparations in vitro. Endocrinology, 79, 875-883.

Ainsworth, L. \& RYAN, K. J. (1967) Steroid hormone transformations by endocrine organs from pregnant mammals. II. Formation and metabolism of progesterone by bovine and sheep placental preparations in vitro. Endocrinology, 81, 1349-1356.

Anderson, A. B. M., Pierrepoint, G. G., Jones, T., Gripriths, K. \& Turnbull, A. G. (1970) Steroid biosynthesis in vitro by foetal and adult sheep adrenal tissue. F. Reprod. Fert. 22, 99-107.

Davies, I. J., Ryan, K. J. \& Petro, Z. (1970) Estrogen synthesis by adrenal-placental tissues of the sheep and the iris monkey in vitro. Endocrinology, 86, 1457-1459.

Diczralusy, E. (1969) Steroid metabolism in the foeto-placental unit. In The Foeto-placental Unit, pp. 65-109. Excerpta Medica Int. Congr. Ser. No. 183.

Ellis, L. C. \& BerLiner, D. L. (1965) Sequential biotransformation of 5-pregnenolone-7 $\alpha{ }^{3} \mathrm{H}$ and progesterone-4- ${ }^{14} \mathrm{C}$ into androgens by mouse testes. Endocrinology, 76, 591-599. 
Lynn, W. S. \& Brown, R. H. (1958) The conversion of progesterone to androgens by testes. F. biol. Chem. 232, 1015-1030.

Pierrepoint, C. G., Anderson, A. B. M., Griffiths, K. \& Turnbull, A. C. (1970a) Investigations into the metabolism in vitro of $\mathrm{C}_{19}$-steroids by the sheep placenta. Biochem. F. 118, 901-902.

Pierrepoint, G. G., Anderson, A. B. M., Griffiths, K. \& Turnbull, A. C. (1970b) Some aspects of steroid metabolism in the sheep placenta. F. Endocr. 47, ii-iii.

Pierrepoint, C. G., Anderson, A. B. M., Harvey, G., Turnbuld, A. C. \& Griffiths, K. (1971) The conversion in vitro of $\mathrm{C}_{19}$-steroids to oestrogen sulphates by the sheep placenta. F. Endocr. 50, 537-538.

Pierrepoznt, G. G., Anderson, A. B. M., Turnbull, A. C. \& Griffiths, K. (1973) In vivo and in vitro studies of steroid metabolism by the sheep placenta. In The Endocrinology of Pregnancy and Parturition: Experimental Studies in the Sheep, pp. 40-53. Ed. C. G. Pierrepoint. Alpha Omega Alpha, Cardiff.

Pierrepoint, C. G., Rossier, G., Thomas, S. J., Wilson, D. W., Evans, B. A. J., John, B. A., Harvey, G. \& Grifriths, K. (1974) Aspects of steroid metabolism in the sheep foetus. In Avortement et Parturition Provoqués, pp. 81-96. Eds. M. J. Bosc, R. Palmer and Cl. Sureau. Masson, Paris.

Slaunwhite, W. R. \& Samuels, L. T. (1956) Progesterone as a precursor of testicular androgens. $\mathcal{F}$. biol. Chem. 220, 341-352. 